\title{
Clinical efficacy of Tiladi Kshara capsule in the management of Mutrashmari (Renal calculus) - Case Study
}

\author{
Biswas $\mathrm{SS}^{1^{*}}$ Gadve $\mathrm{BN}^{2}$ \\ ${ }^{1}$ MS (Scholar), ${ }^{2}$ Associate Professor, Dept. of Shalyatantra, CSMSS, Ayurved \\ Mahavidyalaya Kanchanwadi, Aurangabad, Maharashtra, India \\ *Corresponding author: email: subhashdr91rulz@gmail.com Mob: 09921539069
}

\begin{abstract}
:
Mutrashmari is one of the most common diseases of Mutravahastrotas. In Ayurveda, Mutrashmari is considered as Asthamahagada (eight type of grave disease mentioned by Sushruta). Clinical features of Mutrashmari explained in various Ayurvedic text resembles of urolithiasis in modern science. In Ayurveda various conservative medicine are mentioned for the management Mutrashmari with less side effect, easily available, cost effective and minimum recurrences of stone formation. In this case report 40 years male patient visited in OPD Shalya Tantra with complaint of abdominal pain (radiating pain from loin to groin), nausea and burning micturation. The USG report showed Mutrashmari (Right renal calculus) of $6 \mathrm{~mm}$ since 2 month. The patient was treated with Tiladi Kshara (500mg two times a day) for the period of 1 month. At the end of treatment patient got relief in signs and symptoms and USG report showed no evidence of right renal calculi. Hence this case study showed the clinical effect of Tiladi Kshara in the management of Mutrashmari.
\end{abstract}

Key words: Kshara, Mutrashmari, Tiladikshara, Urolithiasis, Urinary stone.

\section{Introduction:}

Ashmari is known to mankind since long times. In Samhita period Sushruta the father of surgery has explained urinary calculus under the heading of Ashmari. The description of Ashmari is the specific contribution of Acharya Sushruta and included it in the "Ashtamahagad" (eight type of grave disease mentioned). [1] Process of urinary stone formation as described in Sushruta Samhita is as given below- Urination is normal, when movement of Vata is normal in "Mutravaha Strotasa" but when the abnormal movement of Vikrut Vata is present, stagnation of urine in the system takes place. In person, who do not undergo
Shodhana treatment and who is 'Apathyakarnih' the Shleshma Dosha gets aggravated, which saturate the urine in the system. This saturated urine is the material cause for the stone formation. Urinary calculus is the third most common affliction of urinary tract. It typically occurs in middle life during the most productive year. Kidney stone affect 10$12 \%$ of the population in industrialized countries. The average life time risk of stone formation has been reported in the range of $5-10 \%{ }^{[2]}$

The symptoms of Mutrashmari are excruciating pain over nabhi, basti, sevani, and mendra. ${ }^{[3]}$ The urinary stones have peculiar tendency of recurrence. In modern 
science many treatment options are available for Mutrashmari starting from conservative (Hydrotherapy) to minimal invasive surgical intervention (laproscopic surgery) with their won limitations. Surgical options are more as compare to conservative management. Surgical procedure required high expenditure and skilled labour and also have high rate of recurrence. So it is obvious patients turn to alternative of Ayurveda treatment to combat with the disease. In Ayurveda various conservative medicine are mentioned for the management Mutrashmari with less side effect, easily available, cost effective and minimum recurrences of stone formation. Hence, here is an attempt to evaluate the efficacy of Tiladi Kshara in the management of Mutrashmari (Renal Calculi) which is useful due to its Bhedan, Chedan, Mutrala, Anuloman properties in management of Mutrashmari. ${ }^{[4]}$

\section{Case History:}

A male patient, aged 40 years presenting with complaint of pain in the abdomen and back which is radiating pain from loin to groin, nausea and burning micturition since 2 months came in OPD of Shalya tantra CSMSS Ayurved Hospitals, Aurangabad. Patient had taken initial treatment at private hospital but had no relief. Then patient came to our Ayurved Hospital for the management. Nothing significant history was noted by patient regarding surgical, addiction, allergy and family history.
In physical examination PR-78/minregular, BP-110/80mm of $\mathrm{Hg}$, RR-16/min and Temp- $99.4^{0}$ F. In systemic examination CVS (cardiovascular system), CNS (Central Nervous system), RS (Respiratory system) were within normal limit. Per abdominal examination findings were pain at right iliac and right lumbar region is noted. In laboratory investigations $[\mathrm{Hb} \%-12.3 \mathrm{gm} \%$, WBC$8200 / \mathrm{mm}^{3} \quad$ Platelets-4.23 lakhs, Urine microscopic examination:- Pus Cells- 23/hpf, RBC-6-8/hpf,] USG of KUB (Kidney Ureter Bladder) report showed 6 $\mathrm{mm}$ calculus in the lower pole right kidney. In Renal function test blood urea $(28 \mathrm{mg} / \mathrm{dl})$ and serum creatinine $(0.8 \mathrm{mg} / \mathrm{dl})$ showed normal values which indicates that kidney function is normal. So the diagnosis was made Mutrashmari (Right Renal Calculus).

\section{Treatment given:}

The drug Tiladi Kshara was prepared in the pharmacy of institute as per classical method having five ingredients (Table-1). [5] The 500mg capsule of Tiladi Kshara twice daily after meal with normal water was given for one month. The patient was follow up on $7^{\text {th }}, 14^{\text {th }}, 21^{\text {st }}, 28^{\text {th }}$ day of treatment to assess the result of drug. The assessment of relief in signs and symptoms was done by adopting gradation (Table-2). After completion of treatment patient was followed up for further one month and to see any recurrence. 
INTERNATIONAL JOURNAL OF AYUSH CASE REPORTS (IJA-CARE)

website: www.ijacare.in

ISSN: 2457-0443

Table-1: Ingredients of Tiladi Kshara:

\begin{tabular}{|c|c|c|c|c|c|c|}
\hline Dravya & $\begin{array}{l}\text { Latine } \\
\text { Name }\end{array}$ & Ras & Virya & Vipak & Guna & Karma \\
\hline Tila & $\begin{array}{l}\text { Sesamum } \\
\text { orientale } \\
\text { Linn. }\end{array}$ & $\begin{array}{c}\text { Madhura, } \\
\text { Katu, } \\
\text { Tikta, } \\
\text { Kashaya }\end{array}$ & Ushna & Madhura & $\begin{array}{l}\text { Guru, } \\
\text { Snighdha }\end{array}$ & $\begin{array}{c}\text { Snehana, Rasayana, } \\
\text { mutrajanana, }\end{array}$ \\
\hline Apamarga & $\begin{array}{l}\text { Achyranthes } \\
\text { aspera Linn. }\end{array}$ & $\begin{array}{l}\text { Katu, } \\
\text { Tikta }\end{array}$ & Ushna & Katu & $\begin{array}{l}\text { Laghu, } \\
\text { Ruksha, } \\
\text { Tikshna }\end{array}$ & $\begin{array}{c}\text { Ashmarinashana, } \\
\text { Mutrala }\end{array}$ \\
\hline Palasha & \begin{tabular}{|c|} 
Butea \\
monosperma \\
(Lamk) taub \\
\end{tabular} & $\begin{array}{c}\text { Tikta, } \\
\text { Katu, } \\
\text { Kashaya }\end{array}$ & Sheeta & Madhura & $\begin{array}{l}\text { Snighdha, } \\
\text { Laghu }\end{array}$ & $\begin{array}{c}\text { Mutrala, } \\
\text { Stambhana, } \\
\text { Dahanashaka }\end{array}$ \\
\hline Kadali & \begin{tabular}{|c|} 
Musa \\
parandisiaea \\
Linn
\end{tabular} & $\begin{array}{l}\text { Madhura, } \\
\text { Kashaya }\end{array}$ & Sheeta & Madhura & $\begin{array}{l}\text { Guru, } \\
\text { Snighdha }\end{array}$ & $\begin{array}{c}\text { Kaphakaraka, } \\
\text { Balya, } \\
\text { Jeevaniya } \\
\end{array}$ \\
\hline Yava & $\begin{array}{c}\text { Horleum } \\
\text { vulgare Linn }\end{array}$ & $\begin{array}{l}\text { Kashaya, } \\
\text { Madhura }\end{array}$ & Sheeta & Katu & $\begin{array}{l}\text { Ruksha, } \\
\text { Guru, } \\
\text { Pichchhila, } \\
\text { Mridu }\end{array}$ & $\begin{array}{c}\text { Ashmari Bhedana, } \\
\text { Mutrala, } \\
\text { Anulomana }\end{array}$ \\
\hline
\end{tabular}

Table-2: Assessment criteria:

\begin{tabular}{|l|l|l|l|l|}
\hline $\begin{array}{l}\text { Signs and } \\
\text { symptoms }\end{array}$ & Grade 0 & Grade 1 & Grade 2 & Grade 3 \\
\hline Pain & No pain & Mild pain & Moderate pain & Severe pain \\
\hline $\begin{array}{l}\text { Burning } \\
\text { micturition }\end{array}$ & $\begin{array}{l}\text { Absence of } \\
\text { burning } \\
\text { micturition }\end{array}$ & $\begin{array}{l}\text { Occasional } \\
\text { burning } \\
\text { micturition }\end{array}$ & $\begin{array}{l}\text { Burning } \\
\text { micturition in } \\
\text { half of urination }\end{array}$ & $\begin{array}{l}\text { Severe burning } \\
\text { micturition at at } \\
\text { every urination }\end{array}$ \\
\hline
\end{tabular}

Table-3: Observations and results:

\begin{tabular}{|l|l|l|l|l|l|l|}
\hline Complaints & $\begin{array}{l}\mathbf{0} \text { day } \\
\left(\mathbf{B T}^{*}\right)\end{array}$ & $\mathbf{7}^{\text {th }}$ day & $\mathbf{1 4}^{\text {th }}$ day & $\mathbf{2 1}^{\text {st }}$ day & $\mathbf{2 8}^{\text {th }}$ day & $\begin{array}{l}\mathbf{3 0}^{\text {th }} \text { Day } \\
\left(\text { AT }^{*}\right)\end{array}$ \\
\hline Pain & 3 & 3 & 2 & 2 & 0 & 0 \\
\hline $\begin{array}{l}\text { Burning } \\
\text { Micturition }\end{array}$ & 3 & 2 & 1 & 0 & 0 & 0 \\
\hline
\end{tabular}

*BT-Before Treatment AT- After Treatment 


\section{Result and Discussion:}

Mutrashmari is a disease formed due to Vata and Kapha dosha samurcchana. Most of the ingredients of Tiladi Kshara are having Katu, Tikta, Kashaya Rasa, Ushna Virya and Kapha Vata Shamaka properties. As in Mutrashmari, the main Dosha involved is Kapha, the drug pacifies the aggravated Kapha by its above mentioned properties. Kshara have properties like Shodhana, Lekhana, Bhedhan, Pachana and Tridoshagna properties. ${ }^{[6]}$ These properties helped to relief from pain and so on $4 \mathrm{t}$ week or $28^{\text {th }}$ day the patient was free from abdominal pain. Burning micturation was relieved completely on $21^{\text {st }}$ day due to above properties of the drug (Table-3). The formulation probably disintegrates the stone and thus helps to dislodge the Ashmari from its own site. So the U.S.G (K.U.B) was done after 30 days of treatment and report showed that there was no any calculus.

Finally Vata Shamaka property of the drug normalizes the function of Apana Vayu and helps in expulsion of the stones. It also acts as a scrapper for the stone which acts mainly on Kapha Dosha. Kshara is $100 \%$ soluble in water, so it can actively precipitate to counteract the pathogenesis of stone formation and it neutralize acidic media of urine as it behaves as alkaline substance. This formulation can also prevent the stone formation in future also but long term follow up is needed. It is not feasible to say with one month follow up as it was done in this case.

\section{Conclusion:}

This single case study showed that the Tiladi Kshara in capsule has potential to expel the Mutrashmari (Renal stone) and palatable to the patient without side effect. Further study is needed to evaluate its efficacy in more patients so that it can prove beneficial to mankind.

\section{References:}

1. PV Sharma Sushruta Samhita Dalhan commentary, sutrasthan 33/5 Chaukhambha Vishvabharati, Varanasi, reprint ed. 2004 p-316-317.

2. Sofia HN, Manickavasakam K,Walter TM. Prevalence and risk factors of kidney stone. Global Journal for Research Analysis. 2016;5(3):183-187.

3. Ambikadatta Shastrri, Sushruta Samhita, Ayurveda tatva sandipika, Nidan Sthan 3/5 Chaukhambha Sanskrit ansthan Varanasi, reprint ed. 2014 p-311.

4. Ambikadatta Shastri, Sushruta Samhita, Ayurveda tatva sandipika, Chikitsa Sthan 7/22 Chaukhambha Sanskrit ansthan Varanasi, reprint ed. 2014 p-53.

5. Ambikadatta Shastrri, Sushruta Samhita, Ayurveda tatva sandipika, Chikitsa Sthan 7/22 Chaukhambha Sanskrit ansthan Varanasi, reprint ed. 2014 p-53.

6. PV Sharma Sushruta Samhita Dalhan commentary, sutrasthan 11/5 Chaukhambha Vishvabharati, Varanasi, reprint ed. 2004 p-116-117. 
Guarantor: Corresponding author is guarantor of this article and its contents.

Conflict of interest: Author declare that there is no conflict of interest

\section{How to cite this article:}

Biswas SS, Gadve BN Clinical efficacy of Tiladi Kshara capsule in the management of Mutrashmari (Renal calculus) - Case Study. Int. J. AYUSH CaRe. 2017;1(1):10-15. 